\title{
Recent publications on organized crime: the year 2020
}

\author{
Klaus von Lampe ${ }^{1}$ \\ Published online: 19 March 2021 \\ (c) Springer Science+Business Media, LLC, part of Springer Nature 2021
}

This is a list of over 300 English-language publications on organized crime and related topics from the year 2020. Books are included by copyright date. Journal articles are not included by the date they are posted online first, but by the year of the issue or volume once they are formally published. Pertinent publications were identified through searches in various databases, including Google Scholar and Google Books, using search terms including "organized crime," "criminal network," "mafia," "trafficking," and "smuggling." Authors and publishers also provided information. The aim was to list publications that reflect the multi-facetted nature of the study of organized crime, understood broadly to encompass the study of the organization crimes, the study of the organization of criminals, and the study of the organization of social spheres by criminals for criminal purposes. All articles from volume 23 of Trends in Organized Crime were included without a separate examination of their thematic scope.

Aguirre, A. Alonso, Catherina, Richard, Frye, Hailey, Shelley, Louise (2020). Illicit Wildlife Trade, Wet Markets, and COVID-19: Preventing Future Pandemics. World Medical and Health Policy 12(3):256-265.

Agu, Helen U., Gore, Meredith L. (2020). Women in wildlife trafficking in Africa: A synthesis of literature. Global Ecology and Conservation 23(1):e01166.

Albanese, Jay S. (2020). Why Organized Crime Seeks New Criminal Markets. In: Y. Zabyelina, D. van Uhm (Eds.), Illegal Mining: Organized Crime, Corruption, and Ecocide in a Resource-Scarce World (pp. 31-42). Cham: Palgrave Macmillan.

Ambagtsheer, Frederike (2020). Combating Human Trafficking for the Purpose of Organ Removal: Lessons Learned from Prosecuting Criminal Cases. In: J.A.

Klaus von Lampe

Klaus.vonLampe@HWR-Berlin.de

1 Department of Police and Security Management, Berlin School of Economics and Law, Alt-Friedrichsfelde 60, 10315 Berlin, Germany 
Winterdyk, J. Jones (Eds.), The Palgrave International Handbook of Human Trafficking (pp. 1733-1749). Cham: Palgrave Macmillan.

Ambagtsheer, Frederike, Van Balen, Linde (2020). 'I'm not Sherlock Holmes': Suspicions, secrecy and silence of transplant professionals in the human organ trade. European Journal of Criminology 17(6):764-783.

Anderson Baxter, Alexandra Louise (2020). When the Line between Victimization and Criminalization Blurs: The Victim-Offender Overlap Observed in Female Offenders in Cases of Trafficking in Persons for Sexual Exploitation in Australia. Journal of Human Trafficking 6(3):327-338.

Andreatta, Daniela, Favarin, Serena (2020). Features of transnational illicit waste trafficking and crime prevention strategies to tackle it. Global Crime 21(2):130-153.

Antonopoulos, Georgios A., Baratto, Gabriele, Di Nicola, Andrea, Diba, Parisa, Martini, Elisa, Papanicolaou, Georgios, Terenghi, Fiamma (2020). Technology in Human Smuggling and Trafficking: Case Studies from Italy and the United Kingdom. Cham: Springer.

Antonopoulos, Georgios A., Hall, Alexandra, Large, Joanna, Shen, Anqi (2020). Counterfeit goods fraud: an account of its financial management. European Journal on Criminal Policy and Research 26(3):357-378.

Artinopoulou, Vasiliki, Koufouli, Alexandra (2020). Legislation, Policies, and Practices Against Trafficking in Human Beings: The Case of Kosovo. In: J.A. Winterdyk, J. Jones (Eds.), The Palgrave International Handbook of Human Trafficking (pp. 1113-1132). Cham: Palgrave Macmillan.

Askola, Heli (2020). Regional Responses to Human Trafficking in Southeast Asia and Australasia. In: J.A. Winterdyk, J. Jones (Eds.), The Palgrave International Handbook of Human Trafficking (pp. 901-915). Cham: Palgrave Macmillan.

Avery, Simon (2020). For fraud, look under 'serious and organized crime'. Public Money and Management 40(5):407-414.

Aziani, Alberto (2020). Violent disequilibrium: the influence of instability in the economic value of cocaine markets on homicides. Crime, Law and Social Change 74(3):245-272.

Aziani, Alberto, Dugato, Marco, Meneghini, Cecilia (2020). A methodology for estimating the illicit consumption of cigarettes at the country level. Global Crime 21(2):154-184. 
Aziani, Alberto, Favarin, Serena, Campedelli, Gian Maria (2020). Security Governance: Mafia Control over Ordinary Crimes. Journal of Research in Crime and Delinquency 57(4):444-492.

Aziani, Alberto, Favarin, Serena, Campedelli, Gian Maria (2020). A Security Paradox: The Influence Of Governance-Type Organized Crime Over the Surrounding Criminal Environment. British Journal of Criminology 60(4):970-993.

Azis, Avyanthi, Wahyudi, Ridwan (2020). Imperfect Victims and an Imperfect Protocol: Reflecting on the Trafficking Experiences of Indonesian Migrant Fishermen. Journal of Human Trafficking 6(2):156-167.

Baika, Laura, Campana, Paolo (2020). Centrality, Mobility, and Specialization: A Study of Drug Markets in a Non-metropolitan Area in the United Kingdom. Journal of Drug Issues 50(2):107-126.

Balcells, Marc (2020). Old dogs, new tricks: The use of technology by Italian archaeological looters. In: P.C. van Duyne, D. Siegel, G.A. Antonopoulos, J.H. Harvey, K. von Lampe (Eds.), Criminal Defiance in Europe and Beyond: From organised crime to crime-terror nexus (pp. 449-475). The Hague: Eleven International Publishing.

Bales, Kevin, Murphy, Laura T., Silverman, Bernard W. (2020). How many trafficked people are there in Greater New Orleans? Lessons in measurement. Journal of Human Trafficking 6(4):375-387.

Barkoukis, Vassilis, Lazuras, Lambros, Kourelis, Panagiotis (2020). A preliminary investigation of the decision making process towards match fixing. Crime, Law and Social Change 74(1):45-54.

Battisti, Michele, Bernardo, Giovanni, Konstantinidi, Antri, Kourtellos, Andros, Lavezzi, Andrea Mario (2020). Socio-Economic Inequalities and Organized Crime: An Empirical Analysis. In: D. Weisburd, E.U. Savona, B. Hasisi, F. Calderoni (Eds.), Understanding Recruitment to Organized Crime and Terrorism (pp. 205-239). Cham: Springer.

Batura, Olga, op 't Hoog, Gabrielle, van Wanrooij, Niels (2020). Why do we know so little about illicit trade in cultural goods? An analysis of obstacles to collecting reliable data. In: P.C. van Duyne, D. Siegel, G.A. Antonopoulos, J.H. Harvey, K. von Lampe (Eds.), Criminal Defiance in Europe and Beyond: From organised crime to crime-terror nexus (pp. 427-448). The Hague: Eleven International Publishing. 
Bauman, Rebecca (2020). Soldiers for the Mob: The Military as Metaphor for Italian Organized Crime. In: M. Roveri (Ed.), Italy and the Military: Cultural Perspectives from Unification to Contemporary Italy (pp. 331-346). Cham: Palgrave-Macmillan.

Becucci, Stefano (2020). Human Smuggling to Italy through the Libyan Coasts. In: P.C. van Duyne, D. Siegel, G.A. Antonopoulos, J.H. Harvey, K. von Lampe (Eds.), Criminal Defiance in Europe and Beyond: From organised crime to crime-terror nexus (pp. 245-273). The Hague: Eleven International Publishing.

Beka, Agnesa A. (2020). Some features of organized crime in Kosovo. Technium Social Sciences Journal 10(1):201-206.

Belhabib, Dyhia, Le Billon, Philippe, Wrathall, David J. (2020). Narco-Fish: Global fisheries and drug trafficking. Fish and Fisheries 21(5):992-1007.

Bellotti, Elisa, Spencer, Jon, Lord, Nick, Benson, Katie (2020). Counterfeit alcohol distribution: A criminological script network analysis. European Journal of Criminology 17(4):373-398.

Bernet Kempers, Eva (2020). Between Informality and Organized Crime: Criminalization of Small-Scale Mining in the Peruvian Rainforest. In: Y. Zabyelina, D. van Uhm (Eds.), Illegal Mining: Organized Crime, Corruption, and Ecocide in a Resource-Scarce World (pp. 273-298). Cham: Palgrave-Macmillan.

Berruti, Gilda, Palestino, Maria Federica (2020). Contested land and blurred rights in the Land of Fires (Italy). International Planning Studies 25(3):277-288.

Bertola, Federico (2020). Drug Trafficking on Darkmarkets: How Cryptomarkets are Changing Drug Global Trade and the Role of Organized Crime. American Journal of Qualitative Research 4(2):27-34.

Blokland, Arjan, Van Der Leest, Wouter, Soudijn, Melvin (2020). Officially Registered Criminal Careers of Members of Dutch Outlaw Motorcycle Gangs and Their Support Clubs. Deviant Behavior 41(11):1393-1412.

Blom, Nadine (2020). Human Trafficking: An International Response. In: J.A. Winterdyk, J. Jones (Eds.), The Palgrave International Handbook of Human Trafficking (pp. 1275-1298). Cham: Palgrave Macmillan.

Bouchard, Martin (2020). Collaboration and Boundaries in Organized Crime: A Network Perspective. Crime and Justice 49(1):425-469.

Bouche, Vanessa, Bailey, Madeleine (2020). The UNODC Global Report on Trafficking in Persons: An Aspirational Tool with Great Potential. In: J.A. Winterdyk, 
J. Jones (Eds.), The Palgrave International Handbook of Human Trafficking (pp. 163-176). Cham: Palgrave-Macmillan.

Broad, Rosemary, Muraszkiewicz, Julia (2020). The Investigation and Prosecution of Traffickers: Challenges and Opportunities. In: J.A. Winterdyk, J. Jones (Eds.), The Palgrave International Handbook of Human Trafficking (pp. 707-723). Cham: Palgrave Macmillan.

Broadhurst, Roderic (2020). Transnational crime in Asia: Illicit markets and innovation. In: T. Wing Lo, D. Siegel and S.I. Kwok (Eds.), Organized Crime and Corruption Across Borders: Exploring the Belt and Road Initiative (pp. 73-98). London: Routledge.

Brown, Stuart S., Hermann, Margaret G. (2020). Transnational Crime and Black Spots: Rethinking Sovereignty and the Global Economy. Cham: Palgrave-Macmillan.

Bruckmüller, Karin (2020). Trafficking of Human Beings for Organ (Cells and Tissue) Removal. In: J.A. Winterdyk, J. Jones (Eds.), The Palgrave International Handbook of Human Trafficking (pp. 319-337). Cham: Palgrave-Macmillan.

Bruwer, Carina (2020). Smuggling and Trafficking of Illicit Goods by Sea. In: L. Otto (Ed.), Global Challenges in Maritime Security: An Introduction (pp. 49-73). Cham: Springer.

Bryant, Katharine, Landman, Todd (2020). Combatting Human Trafficking since Palermo: What Do We Know about What Works? Journal of Human Trafficking 6(2):119-140.

Brzenchek, Robert M. (2020). Transnational Organized Crime: Intervention, Prevention, and Suppression of Cybersecurity. Lanham, MD: Rowman and Littlefield.

Burcher, Morgan (2020). Social Network Analysis and Law Enforcement: Applications for Intelligence Analysis. Cham: Palgrave Macmillan.

Buszko, Andrzej (2020). Transformation Towards a Market Oriented Economy - an Impetus or Hindrance for Organized Crime in Poland? Olsztyn Economic Journal 15(1):5-22.

Calamunci, Francesca, Drago, Francesco (2020). The Economic Impact of Organized Crime Infiltration in the Legal Economy: Evidence from the Judicial Administration of Organized Crime Firms. Italian Economic Journal 6(2):275-297. 
Calderoni, Francesco, Campedelli, Gian Maria, Comunale, Tommaso, Marchesi, Martina E. Savona, Ernesto U. (2020). Recruitment into organised criminal groups: A systematic review. Trends and Issues in Crime and Criminal Justice 583(1):1-28.

Calderoni, Francesco, Catanese, Salvatore, De Meo, Pasquale, Ficara, Annamaria, Fiumara, Giacomo (2020). Robust link prediction in criminal networks: A case study of the Sicilian Mafia. Expert Systems with Applications 161(1):113,666.

Campana, Paolo (2020). Human Smuggling: Structure and Mechanisms. Crime and Justice 49(1):471-519.

Caneppele, Stefano, Langlois, Fiona, Verschuuren, Pim (2020). Those who counter match-fixing fraudsters: voices from a multistakeholder ecosystem. Crime, Law and Social Change 74(1):13-26.

Carbajal Glass, Fausto (2020). Where the Metal Meets the Flesh: Organized Crime, Violence, and the Illicit Iron Ore Economy in Mexico's Michoacán State. In: Y. Zabyelina, D. van Uhm (Eds.), Illegal Mining: Organized Crime, Corruption, and Ecocide in a Resource-Scarce World (pp. 147-183). Cham: Palgrave Macmillan.

Catino, Maurizio (2020). Italian Organized Crime since 1950. Crime and Justice 49(1):69-140.

Cavallaro, Lucia, Ficara, Annamaria, De Meo, Pasquale, Fiumara, Giacomo, Catanese, Salvatore, Bagdasar, Ovidiu, Song, Wei, Liotta, Antonio (2020). Disrupting resilient criminal networks through data analysis: The case of Sicilian Mafia. PLoS ONE 15(8):e0236476.

Chavez Villegas, Cirenia (2020). Poverty, Aspirations, and Organized Crime in Ciudad Juárez, Mexico. Victims and Offenders 15(3):330-349.

Checchi, Valeria Virginia, Polo, Michele (2020). Blowing in the Wind: The Infiltration of Sicilian Mafia in the Wind Power Business. Italian Economic Journal $6(2): 325-352$.

Childs, Andrew, Coomber, Ross, Bull, Melissa, Barratt, Monica J. (2020). Evolving and Diversifying Selling Practices on Drug Cryptomarkets: An Exploration of OffPlatform "Direct Dealing”. Journal of Drug Issues 50(2):173-190.

Churakova, Irina, van der Westhuizen, Amanda (2020). Human Trafficking in the Russian Federation: Scope of the Problem. In: J.A. Winterdyk, J. Jones (Eds.), The Palgrave International Handbook of Human Trafficking (pp. 1071-1092). Cham: Palgrave Macmillan. 
Cimino, Francesca, Mannu, Daniela (2020). Smuggling, Trafficking, and Exploitation among Unaccompanied Minors Arriving in Friuli Venezia Giulia from the Middle East. Peace Human Rights Governance 4(3):287-309.

Cingano, Federico, Tonello, Marco (2020). Law Enforcement, Social Control and Organized Crime: Evidence from Local Government Dismissals in Italy. Italian Economic Journal 6(2):221-254.

Cockbain, Ella, Bowers, Kate, Vernon, Liam (2020). Using Law Enforcement Data in Trafficking Research. In: J.A. Winterdyk, J. Jones (Eds.), The Palgrave International Handbook of Human Trafficking (pp. 1709-1732). Cham: Palgrave Macmillan.

Columb, Sean (2020). Trading Life: Organ trafficking, illicit networks, and exploitation. Stanford, CA: Stanford University Press.

Comunale, Tommaso, Calderoni, Francesco, Marchesi, Martina, Superchi, Elisa, Campedelli, Gian Maria (2020). Systematic Review of the Social, Psychological and Economic Factors Relating to Involvement and Recruitment into Organized Crime. In: D. Weisburd, E.U. Savona, B. Hasisi, F. Calderoni (Eds.), Understanding Recruitment to Organized Crime and Terrorism (pp. 175-204). Cham: Springer.

Constantinou, Angelo G. (2020). The roles and actions of sex traffickers in Cyprus: an overview. Trends in Organized Crime 23(4):324-349.

Cortes-McPherson, Dolores (2020). Digging into the Mining Subculture: The Dynamics of Trafficking in Persons in the Artisanal and Small-Scale Gold Mining of Peru's Madre de Dios. In: Y. Zabyelina, D. van Uhm (Eds.), Illegal Mining: Organized Crime, Corruption, and Ecocide in a Resource-Scarce World (pp. 359-386). Cham: Palgrave Macmillan.

Cortes-McPherson, Dolores (2020). Labor Trafficking of Men in the Artisanal and Small-Scale Gold Mining Camps of Madre de Dios: A Reflection from the "Diaspora Networks" Perspective. In: J.A. Winterdyk, J. Jones (Eds.), The Palgrave International Handbook of Human Trafficking (pp. 1785-1802). Cham: Palgrave Macmillan.

Dadpay, Ali (2020). An Analysis of Fuel Smuggling in the Middle East as a Single Multinational Market. Journal of Industry, Competition and Trade 20(4):643-656.

Dagnes, Joselle, Donatiello, Davide, Moiso, Valentina, Pellegrino, Davide, Sciarrone, Rocco, Storti, Luca (2020). Mafia infiltration, public administration and local institutions: A comparative study in Northern Italy. European Journal of Criminology 17(5):540-562. 
Dandurand, Yvon, Jahn, Jessica (2020). The Failing International Legal Framework on Migrant Smuggling and Human Trafficking. In: J.A. Winterdyk, J. Jones (Eds.), The Palgrave International Handbook of Human Trafficking (pp. 783-800). Cham: Palgrave Macmillan.

Davies, Jon (2020). Criminological reflections on the regulation and governance of labour exploitation. Trends in Organized Crime 23(1):57-76.

Dean, Laura A. (2020). Diffusing Human Trafficking Policy in Eurasia. Bristol: Policy Press.

De Moor, Sabine, Vandeviver, Christophe, Vander Beken, Tom (2020). Assessing the missing data problem in criminal network analysis using forensic DNA data. Social Networks 61(1):99-106.

Derencinovic, Davor (2020). Human Trafficking in Southeastern Europe: Council of Europe Perspective. In: J.A. Winterdyk, J. Jones (Eds.), The Palgrave International Handbook of Human Trafficking (pp. 1001-1014). Cham: Palgrave Macmillan.

Deuchar, Ross, Harding, Simon, McLean, Robert, Densley, James A. (2020). Deficit or Credit? A Comparative, Qualitative Study of Gender Agency and Female Gang Membership in Los Angeles and Glasgow. Crime and Delinquency 66(8):1087-1114.

Devine, Jennifer A., Currit, Nathan, Reygadas, Yunuen, Liller, Louise I., Allen, Gabrielle (2020). Drug trafficking, cattle ranching and Land use and Land cover change in Guatemala's Maya Biosphere Reserve. Land Use Policy 95(1):104,578.

Dhungel, Rita (2020). "No More Interviews Please": Experiences of Trafficking Survivors in Nepal. In: J.A. Winterdyk, J. Jones (Eds.), The Palgrave International Handbook of Human Trafficking (pp. 227-245). Cham: Palgrave-Macmillan.

Diaz-Cervero, Elba, Barredo, Daniel (2020). Journalistic Coverage of Organized Crime in Mexico: Reporting on the Facts, Security Protocols, and Recurrent Subthemes. International Journal of Communication 14(1):2500-2518.

Diviak, Tomas, Coutinho, James A., Stivala, Alex D. (2020). A Man's world? Comparing the structural positions of men and women in an organized criminal network. Crime, Law and Social Change 74(5):547-569.

Diviak, Tomas, Dijkstra, Jan Kornelis, Snijders, Tom A.B. (2020). Poisonous connections: a case study on a Czech counterfeit alcohol distribution network. Global Crime 21(1):51-73. 
Djordjevic, Sasa, Dobovsek, Bojan (2020). Organised crime in Western Balkans Six at the onset of coronavirus. International Journal of Sociology and Social Policy 40(9-10):807-820.

DoCarmo, Tania E. (2020). Ethical Considerations for Studying Human Trafficking. In: J.A. Winterdyk, J. Jones (Eds.), The Palgrave International Handbook of Human Trafficking (pp. 177-194). Cham: Palgrave-Macmillan.

DoCarmo, Tania E. (2020). Major International Counter-Trafficking Organizations: Addressing Human Trafficking from Multiple Directions. In: J.A. Winterdyk, J. Jones (Eds.), The Palgrave International Handbook of Human Trafficking (pp. 1429-1444). Cham: Palgrave Macmillan.

Doig, Alan, Sproat, Peter (2020). A Policy in Search of an Evidence Base: A credible means of implementation? A UK case study on a central government initiative to address the threat of organised crime involvement in local government procurement. In: P.C. van Duyne, D. Siegel, G.A. Antonopoulos, J.H. Harvey, K. von Lampe (Eds.), Criminal Defiance in Europe and Beyond: From organised crime to crime-terror nexus (pp. 187-216). The Hague: Eleven International Publishing.

Doig, Alan, Sproat, Peter A. (2020). Local responses to a national initiative on organised crime and local government procurement fraud. Journal of Financial Crime 27(1):78-91.

Drury, Lisbeth, Travaglino, Giovanni A. (2020). Demobilising by legitimising: Masculine honour, positive and negative contact, and social activism against criminal organisations. Group Processes and Intergroup Relations 23(3):402-417.

Dugato, Marco, Calderoni, Francesco, Berlusconi, Giulia (2020). Forecasting Organized Crime Homicides: Risk Terrain Modeling of Camorra Violence in Naples, Italy. Journal of Interpersonal Violence 35(19-20):4013-4039.

Dugato, Marco, Calderoni, Francesco, Campedelli, Gian Maria (2020). Measuring Organised Crime Presence at the Municipal Level. Social Indicators Research 147(1):237-261.

Dulin, Adam L., Patino, Jairo (2020). Mexican cartel expansion: a quantitative examination of factors associated with territorial claims. Crime, Law and Social Change 73(3):315-336.

Duong, Kim Ann (2020). Human Trafficking and Migration: Examining the Issues from Gender and Policy Perspectives. In: J.A. Winterdyk, J. Jones (Eds.), The 
Palgrave International Handbook of Human Trafficking (pp. 1819-1833). Cham: Palgrave Macmillan.

Duxbury, Scott, Haynie, Dana L. (2020). The responsiveness of criminal networks to intentional attacks: Disrupting darknet drug trade. PLoS ONE 15(9):e0238019.

Dziewanski, Dariusz (2020). Leaving Gangs in Cape Town: Disengagement as Role Exist. Journal of Contemporary Ethnography 49(4):507-535.

El Khoury, Janane (2020). Combatting Human Trafficking in Lebanon: Prosecution, Protection, and Prevention. In: J.A. Winterdyk, J. Jones (Eds.), The Palgrave International Handbook of Human Trafficking (pp. 1205-1217). Cham: Palgrave Macmillan.

Farrell, Amy, Bright, Katherine, de Vries, Ieke, Pfeffer, Rebecca, Dank, Meredith (2020). Policing labor trafficking in the United States. Trends in Organized Crime 23(1):36-56.

Farrell, Amy, de Vries, Ieke (2020). Measuring the Nature and Prevalence of Human Trafficking. In: J.A. Winterdyk, J. Jones (Eds.), The Palgrave International Handbook of Human Trafficking (pp. 147-162). Cham: Palgrave-Macmillan.

Farrell, Amy, Kane, Brianne (2020). Criminal Justice System Responses to Human Trafficking. In: J.A. Winterdyk, J. Jones (Eds.), The Palgrave International Handbook of Human Trafficking (pp. 641-657). Cham: Palgrave Macmillan.

Farrell, Amy, Wills, Candence, Nicolas, Carlande (2020). Police Engagement in Multidisciplinary Team Approaches to Commercial Sexual Exploitation of Children. In: B. Fox, J.A. Reid, A.J. Masys (Eds.), Science Informed Policing (pp. 195-214). Cham: Springer.

Favarin, Serena, Aziani, Alberto (2020). The Global Waste Trafficking and Its Correlates. Journal of Contemporary Criminal Justice 36(3):351-383.

Fazio, Ida (2020). Illicit trades and smuggling activities on the island of Stromboli, 1808-1816: gender roles during a commercial crisis. Continuity and Change 35(Special Issue 1):11-31.

Fazzi, Luca, Elsen, Susanne (2020). Actors in Social Agriculture Cooperatives Combating Organized Crime in Southern Italy: Cultivating the Ground. Sustainability 12(21):9257.

Finnegan, Jennifer C., Masys, Anthony J. (2020). An Epidemiological Framework for Investigating Organized Crime and Terrorist Networks. In: B. Fox, J.A. Reid, A.J. Masys (Eds.), Science Informed Policing (pp. 19-37). Cham: Springer. 
Fischer Bjelland, Heidi (2020). Conceptions of Success: Understandings of Successful Policing of Human Trafficking. Policing 14(3):712-725.

Fontana, Iole (2020). Migration Crisis, Organised Crime and Domestic Politics in Italy: Unfolding the Interplay. South European Society and Politics 25(1):49-74.

Gallien, Max (2020). Informal Institutions and the Regulation of Smuggling in North Africa. Perspectives on Politics 18(2):492-508.

Gara, Mario, Pauselli, Claudio (2020). Looking at 'Crying Wolf' from a Different Perspective: An Attempt at Detecting Banks Under- and Over-Reporting of Suspicious Transactions. Italian Economic Journal 6(2):299-324.

Geest, Victor, van Koppen, M. Vere, Kleemans, Edward R. (2020). Delinquent Development, Employment and Income in a Sample of Dutch Organized Crime Offenders: Shape, Content, and Correlates of Delinquent Trajectories from Age 12 to 65. In: D. Weisburd, E.U. Savona, B. Hasisi, F. Calderoni (Eds.), Understanding Recruitment to Organized Crime and Terrorism (pp. 309-335). Cham: Springer.

Gibbs, Deborah A., Aboul-Hosn, Sue, Kluckman, Marianne N. (2020). Child Labor Trafficking within The US: A First Look at Allegations Investigated by Florida's Child Welfare Agency. Journal of Human Trafficking 6(4):435-449.

Gilinskiy, Yakov, Siegel, Dina (2020). Organized crime in contemporary Russia. In: T.W. Lo, D. Siegel, S.I. Kwok (Eds.), Organized Crime and Corruption Across Borders: Exploring the Belt and Road Initiative (pp. 153-165). London: Routledge.

Gooch, Kate, Treadwell, James (2020). Prisoner Society in an Era of Psychoactive Substances, Organized Crime, New Drug Markets and Austerity. British Journal of Criminology 60(5):1260-1281.

Gregori, Matteo, Merlone, Ugo (2020). Comparing operational terrorist networks. Trends in Organized Crime 23(3):263-288.

Grubb, Jonathan A. (2020). The Rise of Sex Trafficking Online. In: T.J. Holt, A.M. Bossler (Eds.), The Palgrave Handbook of International Cybercrime and Cyberdeviance (pp. 1151-1175). Cham: Palgrave Macmillan.

Han, Seungbaek (2020). Match-fixing under the state monopoly sports betting system: a case study of the 2011 K-League scandal. Crime, Law and Social Change 74(1):97-113.

Hartmann, Arthur (2020). Twenty-five years of legislation and law enforcement against money laundering in Germany: Facts and opinions. In: P.C. van Duyne, D. Siegel, G.A. Antonopoulos, J.H. Harvey, K. von Lampe (Eds.), Criminal Defiance 
in Europe and Beyond: From organised crime to crime-terror nexus (pp. 325-352). The Hague: Eleven International Publishing.

Hataley, Todd (2020). Trade-based money laundering: organized crime, learning and international trade. Journal of Money Laundering Control 23(3):651-661.

Heber, Anita (2020). Purity or danger? The establishment of sex trafficking as a social problem in Sweden. European Journal of Criminology 17(4):420-440.

Heitmüller, Ulrike, von Lampe, Klaus (2020). The rocker phenomenon in Germany: Perceptions and government responses to outlaw bikers in an historical perspective. In: P.C. van Duyne, D. Siegel, G.A. Antonopoulos, J.H. Harvey, K. von Lampe (Eds.), Criminal Defiance in Europe and Beyond: From organised crime to crime-terror nexus (pp. 477-503). The Hague: Eleven International Publishing.

Hiah, Jing (2020). (Anti-)trafficking for Labor Exploitation in Romania: A Labor Perspective. In: J.A. Winterdyk, J. Jones (Eds.), The Palgrave International Handbook of Human Trafficking (pp. 1133-1149). Cham: Palgrave Macmillan.

Holligan, Chris, McLean, Robert, McHugh, Richard (2020). Exploring County Lines: Criminal Drug Distribution Practices in Scotland. Youth Justice 20(1-2):50-63.

Hounmenou, Charles (2020). Engaging Anti-Human Trafficking Stakeholders in the Research Process. Journal of Human Trafficking 6(1):30-49.

Hughes, Caitlin Elizabeth, Chalmers, Jenny, Bright, David A. (2020). Exploring interrelationships between high-level drug trafficking and other serious and organised crime: an Australian study. Global Crime 21(1):28-50.

Hyslip, Thomas S. (2020). Cybercrime-as-a-Service Operations In: T.J. Holt, A.M. Bossler (Eds.), The Palgrave Handbook of International Cybercrime and Cyberdeviance (pp. 815-846). Cham: Palgrave Macmillan.

Ingrasci, Ombretta (2020). Organised crime's lawyers, from lawful defence to the 'bridge function': The case of the Sicilian Mafia. In: P.C. van Duyne, D. Siegel, G.A. Antonopoulos, J.H. Harvey, K. von Lampe (Eds.), Criminal Defiance in Europe and Beyond: From organised crime to crime-terror nexus (pp. 139-164). The Hague: Eleven International Publishing.

Ireland, Carol A., Lewis, Michael, Lopez, Anthony, Ireland, Jane L. (Eds.) (2020). The Handbook of Collective Violence: Current Developments and Understanding. New York: Routledge. 
Jacobs, James B. (2020). The Rise and Fall of Organized Crime in the United States. Crime and Justice 49(1):17-67.

Jaspers, J.D. (2020). Strong by concealment? How secrecy, trust, and social embeddedness facilitate corporate crime. Crime, Law and Social Change 73(1):55-72. Jobe, Alison (2020). Telling the Right Story at the Right Time: Women Seeking Asylum with Stories of Trafficking into the Sex Industry. Sociology 54(5):936-952.

Jones, Nathan P., Dittmann, W. Layne, Wu, Jun, Reese, Tyler (2020). A mixed methods social network analysis of a cross-border drug network: the Fernando Sanchez organization (FSO). Trends in Organized Crime 23(2):154-182.

Jurek, Alicia L., King, William R. (2020). Structural Responses to Gendered Social Problems: Police Agency Adaptations to Human Trafficking. Police Quarterly 23(1):25-54.

Kakar, Suman (2020). Dynamics of Child Labor Trafficking in Southeast Asia: India. In: J.A. Winterdyk, J. Jones (Eds.), The Palgrave International Handbook of Human Trafficking (pp. 383-340). Cham: Palgrave Macmillan.

Katona, Noemi (2020). Combating trafficking of Hungarian women to Western Europe: a multi-level analysis of the international law enforcement cooperation. Trends in Organized Crime 23(2):115-142.

Kemp, Luke, Zolghadriha, Sanaz, Gill, Paul (2020). Pathways into organized crime: comparing founders and joiners. Trends in Organized Crime 23(3):203-226.

Kingston, Kato Gogo (2020). Concealment of Illegally Obtained Assets in Nigeria: Revisiting the Role of the Churches in Money Laundering. African Journal of International and Comparative Law 28(1):106-121.

Kleemans, Edward, van Koppen, Vere (2020). Organized Crime and Criminal Careers. Crime and Justice 49(1):385-423.

Knust, Nandor, Lingenfelter, Kerttuli (2020). Individual Criminal Responsibility Beyond the State: Human Trafficking as Both a Transnational and an International Crime. In: J.A. Winterdyk, J. Jones (Eds.), The Palgrave International Handbook of Human Trafficking (pp. 1765-1784). Cham: Palgrave Macmillan.

Koilybayev, Medet T., Dilbarkhanova, Zhanat R. (2020). On the Specifics of Studying Organized Crime at the Present Stage. Journal of Advanced Research in Law and Economics 11(3):897-904. 
Kronick, Dorothy (2020). Profits and Violence in Illegal Markets: Evidence from Venezuela. Journal of Conflict Resolution 64(7-8):1499-1523.

Kuschminder, Katie, Triandafyllidou, Anna (2020). Smuggling, Trafficking, and Extortion: New Conceptual and Policy Challenges on the Libyan Route to Europe. Antipode 52(1):206-226.

Lantz, Brendan (2020). Co-offending Group Composition and Violence: The Impact of Sex, Age, and Group Size on Co-offending Violence. Crime and Delinquency 66(1):93-122.

Lasocik, Zbigniew (2020). Response for Human Trafficking in Poland in a Nutshell. In: J.A. Winterdyk, J. Jones (Eds.), The Palgrave International Handbook of Human Trafficking (pp. 1033-1049). Cham: Palgrave Macmillan.

Lauchs, Mark (2020). A Global Survey of Outlaw Motorcycle Gang Formation. Deviant Behavior 41(12):1524-1539.

Lavorgna, Anita (2020). Organized Crime and Cybercrime. In: T.J. Holt, A.M. Bossler (Eds.), The Palgrave Handbook of International Cybercrime and Cyberdeviance (pp. 117-134). Cham: Palgrave Macmillan.

Lavorgna, Anita, Middleton, Stuart E., Pickering, Brian, Neumann, Geoff (2020). FloraGuard: Tackling the Online Illegal Trade in Endangered Plants Through a Cross-Disciplinary ICT-Enabled Methodology. Journal of Contemporary Criminal Justice 36(3):428-450.

Leukfeldt, E.R., Holt, Thomas J. (2020). Examining the Social Organization Practices of Cybercriminals in the Netherlands Online and Offline. International Journal of Offender Therapy and Comparative Criminology 64(5):522-538.

Leukfeldt, E. Rutger, Kruisbergen, Edwin W., Kleemans, Edward R., Roks, Robert A. (2020). Organized Financial Cybercrime: Criminal Cooperation, Logistic Bottlenecks, and Money Flows. In: T.J. Holt, A.M. Bossler (Eds.), The Palgrave Handbook of International Cybercrime and Cyberdeviance (pp. 961-980). Cham: Palgrave Macmillan.

Levi, Michael, Soudijn, Melvin (2020). Understanding the Laundering of Organized Crime Money. Crime and Justice 49(1):579-631.

Liddick, Donald R. Jr. (2020). Transnational Organized Criume and Natural Resources Trafficking: Funding Conflict and Stealing from the World's Most Vulnerable Citizens. Lanham, MD: Lexington Books. 
Lippert, Amy (2020). The Visual Pedagogy of Reform: Picturing White Slavery in America. Journal of Urban History 46(4):854-888.

Lloyd, Anthony (2020). Working for free illegal employment practices, 'off the books' work and the continuum of legality within the service economy. Trends in Organized Crime 23(1):77-93.

Lloyd, Anthony, Antonopoulos, Georgios A., Papanicolaou, Georgios (2020). 'Illegal labour practices, trafficking and exploitation': An introduction to the special issue. Trends in Organized Crime 23(1):1-6.

Lloyd, Danielle (2020). Human Trafficking in Supply Chains and the Way Forward. In: J.A. Winterdyk, J. Jones (Eds.), The Palgrave International Handbook of Human Trafficking (pp. 815-837). Cham: Palgrave Macmillan.

Lo, T. Wing, Li, Li, Kwok, Sharon I. (2020). Control of grand corruption and triad crime in China. In: T.W. Lo, D. Siegel and S.I. Kwok (Eds.), Organized Crime and Corruption Across Borders: Exploring the Belt and Road Initiative (pp. 34-54). London: Routledge.

Loibl, Elvira (2020). Child Trafficking for Adoption Purposes: A Criminological Analysis of the Illegal Adoption Market. In: J.A. Winterdyk, J. Jones (Eds.), The Palgrave International Handbook of Human Trafficking (pp. 401-417). Cham: Palgrave Macmillan.

Lugo, Kristina (2020). Gang Sex Trafficking in the United States. In: J.A. Winterdyk, J. Jones (Eds.), The Palgrave International Handbook of Human Trafficking (pp. 521-540). Cham: Palgrave Macmillan.

Lunstrum, Elizabeth, Giva, Nicia (2020). What drives commercial poaching? From poverty to economic inequality. Biological Conservation 245(1):108,505.

Luong, Hai Thanh (2020). The organisational structure of transnational narcotics trafficking groups in Southeast Asia: A case study of Vietnam's border with Laos. Trends in Organized Crime 23(4):385-411.

Madarie, Renushka, Kruisbergen, Edwin W. (2020). Traffickers in Transit: Analysing the Logistics and Involvement Mechanisms of Organised Crime at Logistical Nodes in the Netherlands: Empirical Results of the Dutch Organised Crime Monitor. In: D. Weisburd, E.U. Savona, B. Hasisi, F. Calderoni (Eds.), Understanding Recruitment to Organized Crime and Terrorism (pp. 277-308). Cham: Springer. 
Magaloni, Beatriz, Robles, Gustavo, Matanock, Alia M., Diaz-Cayeros, Alberto, Romero, Vidal (2020). Living in Fear: The Dynamics of Extortion in Mexico's Drug War. Comparative Political Studies 53(7):1124-1174.

Mapp, Susan C. (2020). Domestic Sex Trafficking of Children. In: J.A. Winterdyk, J. Jones (Eds.), The Palgrave International Handbook of Human Trafficking (pp. 353-370). Cham: Palgrave-Macmillan.

Marsh, Brendan (2020). The Logic of Violence: An Ethnography of Dublin's Illegal Drug Trade. London: Routledge.

Martin, James, Munksgaard, Rasmus, Coomber, Ross, Demant, Jakob, Barrat, Monica J. (2020). Selling Drugs on Darkweb Cryptomarkets: Differentiated Pathways, Risks and Rewards. British Journal of Criminology 60(3):559-578.

Massey, Simon, Rankin, Glynn (2020). Exploiting People for Profit: Trafficking in Human Beings. Cham: Springer.

Matas, David (2020). The Protocol on Trafficking in Persons and Transplant Tourism. In: J.A. Winterdyk, J. Jones (Eds.), The Palgrave International Handbook of Human Trafficking (pp. 489-501). Cham: Palgrave Macmillan.

Mazgaj, Grzegorz (2020). Linking information between databases used for combating organised crime. In: J. Jurczak and M. Plotek (Eds.), Preventing and counteracting crime with the use of advanced data analysis systems (pp. 63-82). Warsaw: Instytut Wydawniczy EuroPrawo.

McCarthy, Lauren A. (2020). A Gendered Perspective on Human Trafficking Perpetrators: Evidence from Russia. Journal of Human Trafficking 6(1):79-94.

McSweeney, Kendra (2020). Cocaine Trafficking and the Transformation of Central American Frontiers. Journal of Latin American Geography 19(3):159-166.

Mehlman-Orozco, Kimberly (2020). Projected heroes and self-perceived manipulators: understanding the duplicitous identities of human traffickers. Trends in Organized Crime 23(2):95-114.

Meneghini, Cecilia, Aziani, Alberto, Dugato, Marco (2020). Modeling the structure and dynamics of transnational illicit networks: an application to cigarette trafficking. Applied Network Science 5(21):1-27.

Middleton, Jennifer (2020). From the Street Corner to the Digital World: How the Digital Age Impacts Sex Trafficking Detection and Data Collection. In: J.A. 
Winterdyk, J. Jones (Eds.), The Palgrave International Handbook of Human Trafficking (pp. 467-480). Cham: Palgrave Macmillan.

Molodikova, Irina (2020). One Step Forward and Two Steps Back: Migration Policy and Human Trafficking in the Russian Federation since the Palermo Protocol of 2020. Journal of Human Trafficking 6(2):141-155.

Moneva, Asier, Caneppele, Stefano (2020). 100\% sure bets? Exploring the precipitation-control strategies of fixed-match informing websites and the environmental features of their networks. Crime, Law and Social Change 74(1):115-133.

Morelato, Marie, Medeiros Bozic, Susana, Rhumorbarbe, Damien, Broseus, Julian, Staehli, Ludovic, Esseiva, Pierre, Roux, Claude, Rossy, Quentin (2020). An insight into Prescription Drugs and Medicine on the AlphaBay Cryptomarket. Journal of Drug Issues 50(1):15-34.

Moreto, William D., Charlton, Richard W., DeWitt, Samuel E., Burton, Christina M. (2020). The Convergence of CAPTURED Fish and People: Examining the Symbiotic Nature of Labor Trafficking and Illegal, Unreported and Unregulated Fishing. Deviant Behavior 41(6):733-749.

Morgan, Anthony, Dowling, Christopher, Voce, Isabella (2020). Australian outlaw motorcycle gang involvement in violent and organised crime. Trends and Issues in Crime and Criminal Justice 586(1):1-18.

Morganti, Margaux, Favarin, Serena Andreatta, Daniela (2020). Illicit Waste Trafficking and Loopholes in the European and Italian Legislation. European Journal on Criminal Policy and Research 26(1):105-133.

Moriconi, Marcelo (2020). Deconstructing match-fixing: a holistic framework for sport integrity policies. Crime, Law and Social Change 74(1):1-12.

Moriconi, Marcelo, de Cima, Cesar (2020). To report, or not to report? From code of silence suppositions within sport to public secrecy realities. Crime, Law and Social Change 74(1):55-76.

Murphy, Tommy E., Rossi, Martin A. (2020). Following the poppy trail: Origins and consequences of Mexican drug cartels. Journal of Development Economics 143(1):102,433.

Murray, Kenneth (2020). In plain sight: developing strategic responses to corporatised organised crime. Journal of Financial Crime 27(2):619-633. 
Murray, Kenneth (2020). When opportunity knocks: mobilizing capabilities on serious organized economic crime. Public Money and Management 40(5):397-406.

Nakamura, Kiminori, Tita, George, Krackhardt, David (2020). Violence in the "balance": a structural analysis of how rivals, allies, and third-parties shape inter-gang violence. Global Crime 21(1):3-27.

Neag, Alexandra (2020). Organised crime legislation in Romania: A case of policy transference? In: P.C. van Duyne, D. Siegel, G.A. Antonopoulos, J.H. Harvey, K. von Lampe (Eds.), Criminal Defiance in Europe and Beyond: From organised crime to crime-terror nexus (pp. 21-49). The Hague: Eleven International Publishing.

Nesvet, Matthew (2020). Migrant Workers, Artisanal Gold Mining, and "MoreThan-Human" Sousveillance in South Africa's Closed Gold Mines. In: Y. Zabyelina, D. van Uhm (Eds.), Illegal Mining: Organized Crime, Corruption, and Ecocide in a Resource-Scarce World (pp. 329-357). Cham: Palgrave Macmillan.

Nguyen, Holly (2020). On the Conceptualization of Criminal Capital. Journal of Research in Crime and Delinquency 57(2):182-216.

Niamkaeo, Sumethat, Robert, Ornprapa (2020). Spatial Relationship of Drug Smuggling in Northern Thailand Using GIS-based Knowledge Discovery. Environment and Natural Resources Journal 18(3):275-282.

Novak, Jurij, Kravtsov, Roman Vladimirovich (2020). The Wild East: An introduction to organised crime in Siberia. In: P.C. van Duyne, D. Siegel, G.A. Antonopoulos, J.H. Harvey, K. von Lampe (Eds.), Criminal Defiance in Europe and Beyond: From organised crime to crime-terror nexus (pp. 77-106). The Hague: Eleven International Publishing.

Nozina, Miroslav, Kraus, Filip (2020). Vietnamese Organized Crime in the Czech Republic. Cham: Palgrave-Macmillan.

Nwadinobi, Eleanor Ann (2020). Trafficking and the Boko Haram Conflict: The Not So Good, the Bad, and the Outright Ugly. In: J.A. Winterdyk, J. Jones (Eds.), The Palgrave International Handbook of Human Trafficking (pp. 419-436). Cham: Palgrave Macmillan.

Otto, Lisa, Jernberg, Leaza (2020). Maritime Piracy and Armed Robbery at Sea. In: L. Otto (Ed.), Global Challenges in Maritime Security: An Introduction (pp. 95-110). Cham: Springer.

Pajon, Laura, Walsh, Dave (2020). Proposing a Theoretical Framework for the Criminal Investigation of Human Trafficking Crimes. Policing 14(2):493-511. 
Paolella, Christopher (2020). Human Trafficking in Medieval Europe: Slavery, Sexual Exploitation, and Prostitution. Amsterdam: Amsterdam University Press.

Paoli, Letizia (2020). What Makes Mafias Different? Crime and Justice 49(1):141-222.

Papanicolaou, Georgios, Boukli, Avi (2020). Human Trafficking in Greece. In: J.A. Winterdyk, J. Jones (Eds.), The Palgrave International Handbook of Human Trafficking (pp. 1093-1112). Cham: Palgrave Macmillan.

Paudel, Kumar, Potter, Gary R., Phelps, Jacob (2020). Conservation enforcement: Insights from people incarcerated for wildlife crimes in Nepal. Conservation Science and Practice 2(2):e137.

Pereira, Victor (2020). Portugal and Human Trafficking (1822-2018). In: J.A. Winterdyk, J. Jones (Eds.), The Palgrave International Handbook of Human Trafficking (pp. 115-130). Cham: Palgrave-Macmillan.

Perez Esparza, Davi, Johnson, Shane D, Gill, Paul (2020). Why did Mexico become a violent country? Assessing the role of firearms trafficked from the U.S. Security Journal 33(2):179-209.

Perkowska, Magdalena (2020). Organised Forms of Illegal Migration: The case of Poland's borders. In: P.C. van Duyne, D. Siegel, G.A. Antonopoulos, J.H. Harvey, K. von Lampe (Eds.), Criminal Defiance in Europe and Beyond: From organised crime to crime-terror nexus (pp. 295-324). The Hague: Eleven International Publishing.

Peters, Bryan C. (2020). Nigerian piracy: Articulating business models using crime script analysis. International Journal of Law, Crime and Justice 62(1):100,410.

Petta Gomes da Costa, De Leon (2020). Organized Crime and the Nation-State: Geopolitics and National Sovereignty. New York: Routledge.

Phillips, Brian J., Rios, Viridiana (2020). Narco-Messages: Competition and Public Communication by Criminal Groups. Latin American Politics and Society 62(1):1-24.

Plotek, Marcin (2020). Organised crime in Poland: An outline of the problem. In: J. Jurczak, M. Plotek (Eds.), Preventing and counteracting crime with the use of advanced data analysis systems (pp. 51-62). Warsaw: Instytut Wydawniczy EuroPrawo. 
Plotek, Marcin (2020). The Role of the Police in Combating Organised Crime in Poland. In: J. Jurczak, M. Plotek (Eds.), Preventing and counteracting crime with the use of advanced data analysis systems (pp. 35-50). Warsaw: Instytut Wydawniczy EuroPrawo.

Plywaczewski, Emil W. (2020). Organized crime in Poland and its control from a Central European perspective. In: T.W. Lo, D. Siegel and S.I. Kwok (Eds.), Organized Crime and Corruption Across Borders: Exploring the Belt and Road Initiative (pp. 220-240). London: Routledge.

Ponce Vazquez, Juan Jose (2020). Islanders and Empire: Smuggling and Political Defiance in Hispaniola, 1580-1690. Cambridge: Cambridge University Press.

Puente Aba, Luz Maria (2020). Defining Child Trafficking for Labor Exploitation, Forced Child Labor, and Child Labor. In: J.A. Winterdyk, J. Jones (Eds.), The Palgrave International Handbook of Human Trafficking (pp. 339-351). Cham: Palgrave Macmillan.

Quinteros Rojas, Daniel, Dufraix Tapia, Roberto, Ramos Rodriguez, Romina (2020). Human Trafficking Cases in Chile: Challenges for Reducing the "Dark Figure". In: J.A. Winterdyk, J. Jones (Eds.), The Palgrave International Handbook of Human Trafficking (pp. 1151-1164). Cham: Palgrave Macmillan.

Raets, Sigrid, Janssens, Jelle (2020). Betwixt and between: Examining the evolution of the crime-terror nexus. In: P.C. van Duyne, D. Siegel, G.A. Antonopoulos, J.H. Harvey, K. von Lampe (Eds.), Criminal Defiance in Europe and Beyond: From organised crime to crime-terror nexus (pp. 531-560). The Hague: Eleven International Publishing.

Reid, Joan, Fox, Bryanna (2020). Human Trafficking and the Darknet: Technology, Innovation, and Evolving Criminal Justice Strategies. In: B. Fox, J.A. Reid, A.J. Masys (Eds.), Science Informed Policing (pp. 77-96). Cham: Springer.

Reuter, Peter, Paoli, Letizia (2020). How Similar Are Modern Criminal Syndicates to Traditional Mafias? Crime and Justice 49(1):223-287.

Reuter, Peter, Tonry, Michael (2020). Organized Crime: Less Than Meets the Eye. Crime and Justice 49(1):1-16.

Ricard-Guay, Alexandra, Hanley, Jill (2020). The Challenge of Addressing Both Forced Labor and Sexual Exploitation. In: J.A. Winterdyk, J. Jones (Eds.), The Palgrave International Handbook of Human Trafficking (pp. 287-302). Cham: Palgrave Macmillan. 
Rodriguez-Lopez, Silvia (2020). Telling Victims from Criminals: Human Trafficking for the Purposes of Criminal Exploitation. In: J.A. Winterdyk, J. Jones (Eds.), The Palgrave International Handbook of Human Trafficking (pp. 303-318). Cham: Palgrave Macmillan.

Roots, Katrin (2020). Human Trafficking in Canada as a Historical Continuation of the 1980s and 1990s Panics over Youth in Sex Trade. In: J.A. Winterdyk, J. Jones (Eds.), The Palgrave International Handbook of Human Trafficking (pp. 97-113). Cham: Palgrave-Macmillan.

Rose, Cecily (2020). The Creation of a Review Mechanism for the UN Convention Against Transnational Organized Crime and Its Protocols. American Journal of International Law 114(1):51-67.

Rosello, Mercedes (2020). Illegal, Unreported and Unregulated (IUU) Fishing as a Maritime Security Concern. In: L. Otto (Ed.), Global Challenges in Maritime Security: An Introduction (pp. 33-47). Cham: Springer.

Sadler Lawrence, Laurie (2020). The Spoiled Supply Chain of Child Labor. In: J.A. Winterdyk, J. Jones (Eds.), The Palgrave International Handbook of Human Trafficking (pp. 371-382). Cham: Palgrave-Macmillan.

Sakib, Najmus A.B.M. (2020). Corruption and organized crime in Bangladesh. In: T.W. Lo, D. Siegel and S.I. Kwok (Eds.), Organized Crime and Corruption Across Borders: Exploring the Belt and Road Initiative (pp. 241-256). London: Routledge.

Salvato, Gerardo, Fiorina, Maria Laura, De Maio, Gabriele, Francescon, Elisa, Ovadia, Daniela, Bernardinelli, Luisa, Santosuosso, Amedeo, Paulesu, Eraldo, Bottini, Gabriella (2020). Pathological risk-propensity typifies Mafia members' cognitive profile. Scientific Reports 10(1):8559.

Salvato, Gerardo, Fiorina, Maria Laura, Ovadia, Daniela, De Maio, Gabriele, Francescon, Elisa, Bottini, Gabriella (2020). Investigating the Psychological Profile of Organized Crime Members. In: D. Weisburd, E.U. Savona, B. Hasisi, F. Calderoni (Eds.), Understanding Recruitment to Organized Crime and Terrorism (pp. 269-275). Cham: Springer.

Sanchez, Gabriella (2020). Victimization, Offending and Resistance in Mexico: Toward Critical Discourse and Grounded Methodologies in Organized Crime Research. Victims and Offenders 15(3):390-393.

Sanchez, Gabriella, Zhang, Sheldon X. (2020). Victimization and Offending in Mexico: The Three-pronged Security Challenges of Trafficking, Kidnapping, and Smuggling. Victims and Offenders 15(3):291-294. 
Sarkar, Siddhartha (2020). The Politics of Human Trafficking: Lessons from Asia and Europe. Lanham, MD: Lexington Books.

Savona, Ernesto U., Calderoni, Francesco, Campedelli, Gian Maria, Comunale, Tommaso, Ferrarini, Marco, Meneghini, Cecilia (2020). The Criminal Careers of Italian Mafia Members. In: D. Weisburd, E.U. Savona, B. Hasisi, F. Calderoni (Eds.), Understanding Recruitment to Organized Crime and Terrorism (pp. 241-267). Cham: Springer.

Scaglione, Attilio (2020). Social change and anti-mafia movements: the 'Addiopizzo' variable. Modern Italy 25(1):17-31.

Scarpa, Silvia (2020). UN Palermo Trafficking Protocol Eighteen Years On: A Critique. In: J.A. Winterdyk, J. Jones (Eds.), The Palgrave International Handbook of Human Trafficking (pp. 623-640). Cham: Palgrave Macmillan.

Scheinost, Miroslav (2020). Organized crime in the Czech Republic. In: T.W. Lo, D. Siegel and S.I. Kwok (Eds.), Organized Crime and Corruption Across Borders: Exploring the Belt and Road Initiative (pp. 204-219). London: Routledge.

Schmidt, Allison (2020). Stowaways at Bohemia's Shores: Undocumented Emigration and People-Smuggling Networks in Interwar East Central Europe. Central European History 53(3):564-583.

Schmidt, Robert (2020). The Queer Ladder of Social Mobility: Illegal Enterprise in the Anthracite Mining Region of Pennsylvania in the Interwar Decades (1917-1945). In: Y. Zabyelina, D. van Uhm (Eds.), Illegal Mining: Organized Crime, Corruption, and Ecocide in a Resource-Scarce World (pp. 43-74). Cham: Palgrave Macmillan.

Schneider, Marius, Nam, Nora Ho Tu (2020). Africa and counterfeit pharmaceuticals in the times of COVID-19. Journal of Intellectual Property Law and Practice 15(6):417-418.

Schumann, Stefan (2020). Corporate Criminal Liability on Human Trafficking. In: J.A. Winterdyk, J. Jones (Eds.), The Palgrave International Handbook of Human Trafficking (pp. 1651-1669). Cham: Palgrave Macmillan.

Schwarz, Corinne, Xing, Chong, Daugherty, Ryan, Watt, Sierra, Britton, Hannah E. (2020). Frontline Workers' Perceptions of Human Trafficking: Warning Signs and Risks in the Midwest. Journal of Human Trafficking 6(1):61-78.

Sclafani, Emanuele, Lavorgna, Anita (2020). Money laundering schemes through real estate markets: A systematic review. In: P.C. van Duyne, D. Siegel, G.A. Antonopoulos, J.H. Harvey, K. von Lampe (Eds.), Criminal Defiance in Europe and 
Beyond: From organised crime to crime-terror nexus (pp. 373-398). The Hague: Eleven International Publishing.

Seddighzadeh, Halleh (2020). The Onset of Global Violent Extremism and Its Nexus with Human Trafficking. In: J.A. Winterdyk, J. Jones (Eds.), The Palgrave International Handbook of Human Trafficking (pp. 481-488). Cham: Palgrave Macmillan.

Selmini, Rossella (2020). Women in Organized Crime. Crime and Justice 49(1):339-383.

Serebrennikova, Anna V., Minyaseva, Tatjana F., Kala, Nagima S., Malinovsky, Alexei A., Malinovskaya, Victoria M., Grynchak, Serhli (2020). Comparative Analysis of Foundations of Legal Regulation of Criminal Liability for Organ Trafficking in the Russian Federation, Kazakhstan, and the European Union. Journal of Advanced Research in Law and Economics 11(4):1405-1415.

Sergi, Anna (2020). Between the Devil and the Deep Blue Sea: A research agenda to investigate organised crime in seaports. In: P.C. van Duyne, D. Siegel, G.A. Antonopoulos, J.H. Harvey, K. von Lampe (Eds.), Criminal Defiance in Europe and Beyond: From organised crime to crime-terror nexus (pp. 165-186). The Hague: Eleven International Publishing.

Sergi, Anna, Storti, Luca (2020). Survive or perish: Organised crime in the port of Montreal and the port of New York/New Jersey. International Journal of Law, Crime and Justice 63(1):100,424.

Shanti, Davina (2020). A New State of Organized Crime: An Analysis of Cybercrime Networks, Activities, and Emerging Threats. Journal of Intelligence, Conflict, and Warfare 3(1):1-13.

Shen, Anqi (2020). Women Who Participate in Illegal Pyramid Selling: Voices from Female Rural Migrant Offenders in China. Asian Journal of Criminology 15(2):91-107.

Shepherd, Chris R., Leupen, Boyd T.C., Siriwat, Penthai, Nijman, Vincent (2020). International wildlife trade, avian influenza, organised crime and the effectiveness of CITES: The Chinese hwamei as a case study. Global Ecology and Conservation 23(1):e01185.

Shuai, Honglan, Liu, Jianhong (2020). Human Trafficking in China. In: J.A. Winterdyk, J. Jones (Eds.), The Palgrave International Handbook of Human Trafficking (pp. 1241-1253). Cham: Palgrave Macmillan. 
Sibley, Marcus A. (2020). Attachments to Victimhood: Anti-Trafficking Narratives and the Criminalization of the Sex Trade. Social and Legal Studies 29(5):699-717.

Siegel, Dina (2020). Diamond Mining, Organized Crime, and Corruption. In: Y. Zabyelina, D. van Uhm (Eds.), Illegal Mining: Organized Crime, Corruption, and Ecocide in a Resource-Scarce World (pp. 185-203). Cham: Palgrave Macmillan.

Siegel, Dina (2020). Russian Organised Crime in Europe. In: P.C. van Duyne, D. Siegel, G.A. Antonopoulos, J.H. Harvey, K. von Lampe (Eds.), Criminal Defiance in Europe and Beyond: From organised crime to crime-terror nexus (pp. 51-75). The Hague: Eleven International Publishing.

Siegel, Dina, Turlubekova, Zhaniya (2020). Organized crime in Kazakhstan. In: T.W. Lo, D. Siegel and S.I. Kwok (Eds.), Organized Crime and Corruption Across Borders: Exploring the Belt and Road Initiative (pp. 166-182). London: Routledge.

Siller, Nicole, van Doore, Kathryn E. (2020). Establishing the Constituent Elements of Trafficking in Persons: Conceptualizing "Transnationality" and "Involvement by an Organized Criminal Group”. In: J.A. Winterdyk, J. Jones (Eds.), The Palgrave International Handbook of Human Trafficking (pp. 271-283). Cham: Palgrave Macmillan.

Smalcerz, Joanna (2020). Smuggling the Renaissance: The Illicit Export of Artworks Out of Italy, 1861-1909. Leiden: Brill.

Smith, Chris M. (2020). Exogenous Shocks, the Criminal Elite, and Increasing Gender Inequality in Chicago Organized Crime. American Sociological Review 85(5):895-923.

Sollund, Ragnhild Aslaug, Runhovde, Siv Rebeka (2020). Responses to Wildlife Crime in Post-Colonial Times. Who Fares Best? British Journal of Criminology 60(4):1014-1033.

Sosnowski, Monique C., Weis, Judith S., Petrossian, Gohar A. (2020). Using Crime Script Analysis to Understand the Illegal Harvesting of Live Corals: Case Studies From Indonesia and Fiji. Journal of Contemporary Criminal Justice 36(3):384-402.

Sotiriou, Konstantinos-Orfeas (2020). Parallelae Vitae: Antiquities Smuggling and Hidden Incomes in Greece. International Journal of Cultural Property 27(3):417-436.

Soudijn, M.R.J., de Been, W.H.J. (2020). Law enforcement and money laundering: Big data is coming. In: P.C. van Duyne, D. Siegel, G.A. Antonopoulos, J.H. Harvey, K. von Lampe (Eds.), Criminal Defiance in Europe and Beyond: From 
organised crime to crime-terror nexus (pp. 399-425). The Hague: Eleven International Publishing.

Spapens, Toine, Moors, Hans (2020). Intergenerational transmission and organised crime. A study of seven families in the south of the Netherlands. Trends in Organized Crime 23(3):227-241.

Spicer, Jack, Moyle, Leah, Coomber, Ross (2020). The variable and evolving nature of 'cuckooing' as a form of criminal exploitation in street level drug markets. Trends in Organized Crime 23(4):301-323.

Stassen, Richard, Ceccato, Vania (2020). Environmental and Wildlife Crime in Sweden from 2000 to 2017. Journal of Contemporary Criminal Justice 36(3):403-427.

Sullivan, Trudy, Smith, Julia, Ombler, Franz, Brayley-Morris, Helen (2020). Prioritising the investigation of organised crime. Policing and Society 30(3):327-348.

Sumaila, U., Zeller, D., Hood, L., Palomares, M., Li, Y., Pauly, D. (2020). Illicit trade in marine fish catch and its effects on ecosystems and people worldwide. Science Advances 6(9):eaaz3801.

Sussman, Jeffrey (2020). Big Apple Gangsters: The Rise and Decline of the Mob in New York. Lanham, MD: Rowman and Littlefield.

Tak, Minhyeok, Sam, Michael P., Choi, Chang-Hwan (2020). Too much at stake to uphold sport integrity? High-performance athletes' involvement in match-fixing. Crime, Law and Social Change 74(1):27-44.

Tan, Shih Joo, Segrave, Marie (2020). An Examination of Counter Trafficking Responses in the Asian Region: Hong Kong and Singapore. In: J.A. Winterdyk, J. Jones (Eds.), The Palgrave International Handbook of Human Trafficking (pp. 917-934). Cham: Palgrave Macmillan.

Tapia, Mike (2020). Gangs in the El Paso-Juárez borderland: the role of history and geography in shaping criminal subcultures. Trends in Organized Crime 23(4):367-384.

Teichmann, Fabian (2020). Recent trends in money laundering. Crime, Law and Social Change 73(2):237-247.

Teichmann, Fabian Maximilian, Falker, Marie-Christin (2020). Money laundering through consulting companies. Journal of Financial Regulation and Compliance 28(3):485-500. 
Tennant, Ian (2020). The Promise of Palermo: A political history of the UN Convention against Transnational Organized Crime. Geneva: Global Initiative against Transnational Organized Crime.

Thachuk, Kimberley L. (2020). Warlords and Their Black Holes: The Plunder of Mining Regions in Afghanistan and the Central African Republic by Organized Crime. In: Y. Zabyelina, D. van Uhm (Eds.), Illegal Mining: Organized Crime, Corruption, and Ecocide in a Resource-Scarce World (pp. 205-237). Cham: Palgrave Macmillan.

Toledo, A.S.O., Carpi, Laura C., Atman, A.P.F. (2020). Diversity Analysis Exposes Unexpected Key Roles in Multiplex Crime Networks. In: H. Barbosa, J. GomesGardenes, B. Goncalves, G. Mangioni, R. Menezes, M. Oliveira (Eds.), Complex Networks XI: Proceedings of the 11th Conference on Complex Networks CompleNet 2020 (pp. 371-382). Cham: Springer.

Trautman, Laurie, Moeller, Mary (2020). The Role of the Border and Border Policies in Efforts to Combat Human Trafficking: A Case Study of the Cascadia Region of the US-Canada Border. In: J.A. Winterdyk, J. Jones (Eds.), The Palgrave International Handbook of Human Trafficking (pp. 985-999). Cham: Palgrave Macmillan.

Travaglino, Giovanni A., Drury, Lisbeth (2020). The Secret Power of Criminal Organizations: A Social Psychological Approach. Cham: Springer.

Troncoso, Fredy, Weber, Richard (2020). A novel approach to detect associations in criminal networks. Decision Support Systems 128(1):113,159.

Trounson, Justin, Pfeifer, Jeffrey (2020). The Human Trafficking of Men: The Forgotten Few. In: J.A. Winterdyk, J. Jones (Eds.), The Palgrave International Handbook of Human Trafficking (pp. 541-555). Cham: Palgrave Macmillan.

Ünal, Mustafa Cosar (2020). Deciphering the crime-terror Nexus: an empirical analysis of the structural characteristics of terrorists in Narco-terror networks. Crime, Law and Social Change 73(2):181-216.

van de Ven, Katinka, Dunn, Matthew, Mulrooney, Kyle (2020). Performance and image enhancing drug (PIED) producers and suppliers: a retrospective content analysis of PIED-provider cases in Australia from 2010-2016. Trends in Organized Crime 23(2):143-153.

van der Valk, Naomi, Bisschop, Lieselot, van Swaaningen, Rene (2020). When Gold Speaks, Every Tongue Is Silent: The Thin Line Between Legal, Illegal, and Informal in Peru's Gold Supply Chain. In: Y. Zabyelina, D. van Uhm (Eds.), Illegal 
Mining: Organized Crime, Corruption, and Ecocide in a Resource-Scarce World (pp. 299-327). Cham: Palgrave Macmillan.

van der Vorm, Benny, van Duyne, Petrus C. (2020). The retribution of the Erinyes: Combatting outlaw motorcycle gangs from the perspective of 'undermining' criminality. In: P.C. van Duyne, D. Siegel, G.A. Antonopoulos, J.H. Harvey, K. von Lampe (Eds.), Criminal Defiance in Europe and Beyond: From organised crime to crime-terror nexus (pp. 505-530). The Hague: Eleven International Publishing.

van der Watt, Marcel, Kruger, Beatri (2020). Breaking Bondages: Control Methods, "Juju," and Human Trafficking. In: J.A. Winterdyk, J. Jones (Eds.), The Palgrave International Handbook of Human Trafficking (pp. 935-951). Cham: Palgrave Macmillan.

van der Zee, Kirsten, van Walbeek, Corne, Magadla, Sibahle (2020). Illicit/cheap cigarettes in South Africa. Trends in Organized Crime 23(3):242-262.

van Dijk, Jan (2020). Measuring Trafficking in Persons Better: Problems and Prospects. In: J.A. Winterdyk, J. Jones (Eds.), The Palgrave International Handbook of Human Trafficking (pp. 1671-1688). Cham: Palgrave Macmillan.

van Duyne, Petrus C., Siegel, Dina, Antonopoulos, Georgios A., Harvey, Jackie H., von Lampe, Klaus (Eds.) (2020). Criminal Defiance in Europe and Beyond: From organised crime to crime-terror nexus. The Hague: Eleven International Publishing.

van Duyne, Petrus C., Svyatokum, Igor (2020). Corruption and oligarchy in Ukraine: The tenacity of a problem. In: P.C. van Duyne, D. Siegel, G.A. Antonopoulos, J.H. Harvey, K. von Lampe (Eds.), Criminal Defiance in Europe and Beyond: From organised crime to crime-terror nexus (pp. 107-138). The Hague: Eleven International Publishing.

van Meeteren, Masja, Bannink, Sanne (2020). A Transnational Field Approach to the Study of Labor Trafficking. In: J.A. Winterdyk, J. Jones (Eds.), The Palgrave International Handbook of Human Trafficking (pp. 1751-1763). Cham: Palgrave Macmillan.

van Meeteren, Masja, Hiah, Jing (2020). Self-Identification of Victimization of Labor Trafficking. In: J.A. Winterdyk, J. Jones (Eds.), The Palgrave International Handbook of Human Trafficking (pp. 1605-1618). Cham: Palgrave Macmillan.

van Rij, Jorn, McAlister, Ruth (2020). Using Criminal Routines and Techniques to Predict and Prevent the Sexual Exploitation of Eastern-European Women in Western Europe. In: J.A. Winterdyk, J. Jones (Eds.), The Palgrave International Handbook of Human Trafficking (pp. 1689-1708). Cham: Palgrave Macmillan. 
van Uhm, Daan (2020). Chinese wildlife trafficking networks along the Silk Road. In: T.W. Lo, D. Siegel and S.I. Kwok (Eds.), Organized Crime and Corruption Across Borders: Exploring the Belt and Road Initiative (pp. 114-133). London: Routledge.

van Uhm, Daan (2020). The Diversification of Organized Crime into Gold Mining: Domination, Crime Convergence, and Ecocide in Darién, Colombia. In: Y. Zabyelina, D. van Uhm (Eds.), Illegal Mining: Organized Crime, Corruption, and Ecocide in a Resource-Scarce World (pp. 105-146). Cham: Palgrave Macmillan.

van Uhm, Daan, Spapens, Toine (2020). Illegal Trade in Protected Birds in the Netherlands: Three criminological perspectives. In: P.C. van Duyne, D. Siegel, G.A. Antonopoulos, J.H. Harvey, K. von Lampe (Eds.), Criminal Defiance in Europe and Beyond: From organised crime to crime-terror nexus (pp. 217-243). The Hague: Eleven International Publishing.

Varese, Federico (2020). How Mafias Migrate: Transplantation, Functional Diversification, and Separation. Crime and Justice 49(1):289-337.

Viseur Sellers, Patricia, Getgen Kestenbaum, Jocelyn (2020). Missing in Action: The International Crime of the Slave Trade. Journal of International Criminal Justice 18(2):517-542.

Visschers, Jonas, Paoli, Letizia, Deshpande, Abhishek (2020). Match-fixing: Football referees' attitudes and experiences. Crime, Law and Social Change 74(1):77-95.

Volodko, Ada, Cockbain, Ella, Kleinberg, Bennett (2020). "Spotting the signs" of trafficking recruitment online: exploring the characteristics of advertisements targeted at migrant job-seekers. Trends in Organized Crime 23(1):7-35.

von Lampe, Klaus, Blokland, Arjan (2020). Outlaw Motorcycle Clubs and Organized Crime. Crime and Justice 49(1):521-578.

Wagner, Livia, Hunter, Marcena (2020). Links Between Artisanal and Small-Scale Gold Mining and Organized Crime in Latin America and Africa. In: Y. Zabyelina, D. van Uhm (Eds.), Illegal Mining: Organized Crime, Corruption, and Ecocide in a Resource-Scarce World (pp. 77-104). Cham: Palgrave Macmillan.

Walters, Reece, Fuentes Loureiro, Maria Angeles (2020). Waste Crime and the Global Transference of Hazardous Substances: A Southern Green Perspective. Critical Criminology 28(3):463-480. 
Wang, Peng (2020). How to Engage in Illegal Transactions: Resolving Risk and Uncertainty in Corrupt Dealings. British Journal of Criminology 60(5):1282-1301.

Weide, Robert D. (2020). The Invisible Hand of the State: A Critical Historical Analysis of Prison Gangs in California. Prison Journal 100(3):312-331.

Weigand, Florian (2020). Conflict and Transnational Crime: Borders, Bullets \& Business in Southeast Asia. Cheltenham: Edward Elgar.

Weisburd, David, Savona, Ernesto U., Hasisi, Badi, Calderoni, Francesco (Eds.) (2020). Understanding Recruitment to Organized Crime and Terrorism. Cham: Springer.

Whittaker, Andrew, Densley, James, Cheston, Len, Tyrell, Tajae, Higgins, Martyn, Felix-Baptiste, Claire, Havard, Tirion (2020). Reluctant Gangsters Revisited: The Evolution of Gangs from Postcodes to Profits. European Journal on Criminal Policy and Research 26(1):1-22.

Whittle, Joseph, Antonopoulos, Georgios A. (2020). Assessing the Operation of Irregular Migration from Eritrea and the Smuggling/Criminality Nexus. In: P.C. van Duyne, D. Siegel, G.A. Antonopoulos, J.H. Harvey, K. von Lampe (Eds.), Criminal Defiance in Europe and Beyond: From organised crime to crime-terror nexus (pp. 275-294). The Hague: Eleven International Publishing.

Williamson, Kim Ann (2020). Tackling Modern Slavery and Human Trafficking in Wales. In: J.A. Winterdyk, J. Jones (Eds.), The Palgrave International Handbook of Human Trafficking (pp. 1051-1070). Cham: Palgrave Macmillan.

Winterdyk, John (2020). Explaining Human Trafficking: Modern Day-Slavery. In: J.A. Winterdyk, J. Jones (Eds.), The Palgrave International Handbook of Human Trafficking (pp. 1257-1274). Cham: Palgrave Macmillan.

Winterdyk, John A., Jones, Jackie (Eds.) (2020). The Palgrave International Handbook of Human Trafficking. Cham: Springer.

Witbooi, Emma, Ali, Kamal-Deen, Santosa, Mas Achmad, Hurley, Gail, Husein, Yunus, Maharaj, Sarika, Okafor-Yarwood, Ifesinachi, Arroyo Quiroz, Ines, Salas, Omar (2020). Organized crime in the fisheries sector threatens a sustainable ocean economy. Nature 588(1):48-56.

Wong, Rebecca W.Y. (2020). Protected wildlife on the One Belt, One Road: A case study of illegal tiger skin trade. In: T.W. Lo, D. Siegel and S.I. Kwok (Eds.), 
Organized Crime and Corruption Across Borders: Exploring the Belt and Road Initiative (pp. 134-150). London: Routledge.

Wyatt, Tanya, van Uhm, Daan, Nurse, Angus (2020). Differentiating criminal networks in the illegal wildlife trade: organized, corporate and disorganized crime. Trends in Organized Crime 23(4):350-366.

Zabyelina, Yuliya, Kalczynski, Nicole (2020). Shadowy Deals with "Sunny Stone": Organized Crime, Informal Mining, and the Illicit Trade of Amber in Ukraine. In: Y. Zabyelina, D. van Uhm (Eds.), Illegal Mining: Organized Crime, Corruption, and Ecocide in a Resource-Scarce World (pp. 241-272). Cham: Palgrave Macmillan.

Zabyelina, Yuliya, van Uhm, Daan (Eds.) (2020). Illegal Mining: Organized Crime, Corruption, and Ecocide in a Resource-Scarce World. Cham: Palgrave Macmillan.

Zabyelina, Yuliya, van Uhm, Daan (2020). The New Eldorado: Organized Crime, Informal Mining, and the Global Scarcity of Metals and Minerals. In: Y. Zabyelina, D. van Uhm (Eds.), Illegal Mining: Organized Crime, Corruption, and Ecocide in a Resource-Scarce World (pp. 3-30). Cham: Palgrave-Macmillan.

Zavoli, Ilaria, King, Colin (2020). Preventive AML in the UK property market: Inside views from the sector. In: P.C. van Duyne, D. Siegel, G.A. Antonopoulos, J.H. Harvey, K. von Lampe (Eds.), Criminal Defiance in Europe and Beyond: From organised crime to crime-terror nexus (pp. 353-371). The Hague: Eleven International Publishing.

Publisher's note Springer Nature remains neutral with regard to jurisdictional claims in published maps and institutional affiliations. 